\title{
Corporate Profitability and Capital Structure: The Case of the Machinery Industry Firms of the Tokyo Stock Exchange
}

\author{
Chikashi Tsuji ${ }^{1}$ \\ ${ }^{1}$ Faculty of Economics, Chuo University, Tokyo, Japan \\ Correspondence: Chikashi Tsuji, Faculty of Economics, Chuo University, 742-1 Higashinakano Hachioji-shi, Tokyo \\ 192-0393, Japan. Tel: 81-42-674-2211. E-mail: mail_sec_low@minos.ocn.ne.jp
}

Received: March 21, 2013

Accepted: April 7, 2013

Online Published: May 12, 2013

doi:10.5430/ijba.v4n3p14

URL: http://dx.doi.org/10.5430/ijba.v4n3p14

\begin{abstract}
This paper examines the relations between corporate profitability and capital structures of the machinery industry firms listed on the Tokyo Stock Exchange. Some theories and models predict different relations between corporate profitability and firms' capital structures. In this paper, we find that in the Japanese machinery industry, the relations between firm profitability and leverage ratio are generally negative. In addition, we also find that about $60 \%$ of the total debt to total asset ratio can be explained by our firm profitability variables in the previous year.
\end{abstract}

Keywords: capital structure, debt ratio, firm profitability, Japanese machinery industry, panel data analysis

\section{Introduction}

Many determinants of the corporate capital structure were nominated and empirically examined in the US (For example, Fama and French (2002), Frank and Goyal (2003, 2009), and Lemmon et al. (2008)). Further, several theories predict different relations between the corporate profitability and its capital structure. For example, the trade-off theory suggests that taxation and deadweight bankruptcy costs are important for the capital structure. The pecking order theory developed by Myers (1984) suggests that the financing order of firms, such as retained earnings, debt, and then equity, are important for the corporate capital structure. Further, the recent notion of the market timing hypothesis suggests that the timing of corporate financing based on the capital market conditions is the key for the capital structure. Also, agency theory suggests that the free cash flow problems and being disciplined by debts are important for the corporate capital structure. Moreover, there are several related recent studies in the US such as Margaritis and Psillaki (2010), Gungoraydinoglu and Öztekin (2011), Wu and Au Yeung (2012), and Fier et al. (2013); however, in contrast to the accumulations of theories and empirical studies in the US as above, as far as we know, there would be little empirical research on the issue of capital structure by exploiting the Japanese data.

Hence based on these research backgrounds, the objective of this paper is to empirically examine the relationships between corporate profitability and capital structure in Japan. In this paper, we focus on the linkage of the corporate profitability and the capital structure of the Tokyo Stock Exchange (TSE) machinery industry firms. The reason of focusing on this industry is that this is one of the most representative industries in Japan. The contributions of this study are as follows. First, we find that in the Japanese industry, the relations between firm profitability and leverage ratio are generally negative. Second, we also find that about $60 \%$ of the total debt to total asset ratio can be explained by our corporate profitability variables in the previous year. Moreover, we reveal that in the Japanese machinery industry, liquid debt is more important in considering the relations between firm profitability and capital structure. The rest of the paper is organized as follows. Section 2 performs discussions, Section 3 describes our data, Section 4 documents our analyzing methodology, Section 5 explains our empirical results, and Section 6 summarizes the paper.

\section{Discussion}

This section discusses the predictions of some theories regarding the relations between corporate profitability and capital structure. First, when firms have strong profitability, financial distress costs of these firms shall be low. Hence profitable firms consider the tax shields more valuable. Therefore, from the viewpoints of lower distress costs and the tax shield effect, profitable firms borrow more, thus the linkage of profitability and debt ratios shall be positive.

Second, from the viewpoint of the agency cost arguments, as Jensen (1986) argues, profitable firms are likely to face severe free cash flow problems. Hence, profitable firms should have more debt because these firms should be 
disciplined by more debt. Thus the agency theory suggests that ideally, the relations between debt ratio and firm profitability shall be positive.

Third, the pecking order theory suggests that firms prefer internal finance compared with external funds. Therefore, profitable firms have more internal funds, thus they should have less debt. Hence according to the pecking order theory, firm leverage and firm profitability should be negatively related.

Furthermore, there are some arguments based on the trade-off theory. For example, Strebulaev (2007) suggests that a dynamic trade-off model predicts that the relation between leverage and profitability can be negative due to various frictions. Further, in the US empirical study of Kayhan and Titman (2007) shows that leverage and profitability are negatively related and they suggest that firms passively accumulate their profits.

\section{Data}

In this paper, we exploit the stacked firm data from the fiscal year of 1981 to 2011 and we also use the pooled regressions in our empirical tests. In our regressions, the dependent variables are the TSE First Section machinery industry firms' debt ratios. More concretely, we use two kinds of debt ratios: TDA denotes the total debt (book-value) to total asset (book-value) ratio and LDA denotes the fixed liability (book-value) to total asset (book-value) ratio.

Regarding the explanatory variables, SALESA denotes the sales to total asset ratio, MARGA denotes the gross margin to total asset ratio, OPPA denotes the operating profit to total asset ratio, ORPA denotes the ordinary profit to total asset ratio, EBITA denotes the earnings before interest and tax (EBIT) to total asset ratio, CFA denotes the cash flow to total asset ratio, and NIA denotes the net income to total asset ratio. Further, MARGS denotes the gross margin to sales ratio, OPPS denotes the operating profit to sales ratio, ORPS denotes the ordinary profit to sales ratio, EBITS is the EBIT to sales ratio, CFS is the cash flow to sales ratio, and NIS denotes the net income to sales ratio.

Moreover, in our regressions, we use three kinds of control variables: LNSIZE is the log natural of market capitalization, TANG is the tangible fixed asset divided by total asset, and OLD denotes the number of the years after establishment of each firm. The data to construct all variables are obtained from the Quick Corp.

\section{Method}

In our empirical tests, we use panel data analyses and we also use several models. The first is the single profitability variable model including three control variables as following panel regression model (1):

$$
L D A_{i, t+1}=\delta_{0}+\delta_{1} X_{i, t}+\delta_{2} L N S I Z E_{i, t}+\delta_{3} T A N G_{i, t}+\delta_{4} O L D_{i, t}+\mu_{i, t+1} .
$$

Where $X_{i, t}$ denotes the corporate profitability variable, namely, SALESA, MARGA, OPPA, ORPA, EBITA, CFA, NIA, MARGS, OPPS, ORPS, EBITS, CFS, or NIS. We also examine the following two full models (2) and (3).

$$
\begin{aligned}
& L D A_{i, t+1}=\varphi_{0}+\varphi_{1} \operatorname{SALESA}_{i, t}+\varphi_{2} \text { MARGA }_{i, t}+\varphi_{3} \mathrm{OPPA}_{i, t}+\varphi_{4} \mathrm{ORPA}_{i, t}+\varphi_{5} E B I T A_{i, t} \\
& +\varphi_{6} \mathrm{CFA}_{i, t}+\varphi_{7} \mathrm{NIA}_{i, t}+\varphi_{8} \text { LNSIZE }_{i, t}+\varphi_{9} \text { TANG }_{i, t}+\varphi_{10} \mathrm{OLD}_{i, t}+\kappa_{i, t+1} \\
& L D A_{i, t+1}=\varphi_{0}+\varphi_{1} \text { MARGS }_{i, t}+\varphi_{2} \text { OPPS }_{i, t}+\varphi_{3} \text { ORPS }_{i, t}+\varphi_{4} \text { EBITS }_{i, t}+\varphi_{5} C F S_{i, t} \\
& +\varphi_{6} N_{I S} S_{i, t}+\varphi_{7} L_{N S I Z E_{i, t}}+\varphi_{8} T_{A N G_{i, t}}+\varphi_{9} O L D_{i, t}+\kappa_{i, t+1}
\end{aligned}
$$

Further, we also test the following pooled regression models (4) to (6) by exchanging the dependent variable from LDA to TDA:

$$
T D A_{i, t+1}=\delta_{0}+\delta_{1} X_{i, t}+\delta_{2} L N S I Z E_{i, t}+\delta_{3} T A N G_{i, t}+\delta_{4} O L D_{i, t}+\mu_{i, t+1} .
$$

Where again, $X_{i, t}$ denotes the corporate profitability variable, that is, SALESA, MARGA, OPPA, ORPA, EBITA, CFA, NIA, MARGS, OPPS, ORPS, EBITS, CFS, or NIS. In addition, the full models are as follows.

$$
\begin{aligned}
& T D A_{i, t+1}=\varphi_{0}+\varphi_{1} S A L E S A_{i, t}+\varphi_{2} \text { MARGA }_{i, t}+\varphi_{3} O P P A_{i, t}+\varphi_{4} O R P A_{i, t}+\varphi_{5} E B I T A_{i, t} \\
& +\varphi_{6} C_{F A_{i, t}}+\varphi_{7} N I A_{i, t}+\varphi_{8} L_{N S I Z E_{i, t}}+\varphi_{9} T A N G_{i, t}+\varphi_{10} O L D_{i, t}+\kappa_{i, t+1} \\
& T D A_{i, t+1}=\varphi_{0}+\varphi_{1} \text { MARGS }_{i, t}+\varphi_{2} \operatorname{OPPS}_{i, t}+\varphi_{3} \mathrm{ORPS}_{i, t}+\varphi_{4} \text { EBITS }_{i, t}+\varphi_{5} \mathrm{CFS}_{i, t} \\
& +\varphi_{6} N I S_{i, t}+\varphi_{7} L_{N S I Z E_{i, t}}+\varphi_{8} T_{A N G_{i, t}}+\varphi_{9} O L D_{i, t}+\kappa_{i, t+1}
\end{aligned}
$$

\section{Empirical Results}

First, we exhibit the descriptive statistics for our employed variables of the Japanese machinery industry firms of the TSE First Section in Table 1. These are the statistics as to the panel data from the fiscal year of 1981 to 2011, and we can overview their statistic characteristics by using this table. The numbers of the stacked data are in cross-section, 
73, in time-series, 31-years, and 2263 pooled data.

Next, we show the results of our pooled regressions from Tables 2 to 5 . First, from Tables 2 to 3, we understand that the relations between firm profitability and leverage ratio constructed by using the fixed liability are all statistically significantly negative. In addition, the results of our full models (2) and (3) in Tables 2 and 3 suggest that about $30 \%$ to $40 \%$ of the LDA can be explained by our profitability variables in the previous year. Further, from the results in Tables 4 to 5, we understand that the relations between corporate profitability and leverage ratio constructed by using the total debt are all statistically significantly negative except for SALESA in Table 4. Furthermore, the results of our full models (5) and (6) in Tables 4 and 5 indicate that about $60 \%$ of the TDA can be explained by our profitability variables in the previous year.

Table 1. Descriptive statistics for the analyzed variables of the Tokyo Stock Exchange machinery industry firms: Balanced panel data for the fiscal year from 1981 to 2011

\begin{tabular}{lccccccccc}
\hline & TDA & LDA & LNSIZE & TANG & OLD & SALESA & MARGA & OPPA & ORPA \\
\hline Mean & 0.561 & 0.163 & 3.893 & 0.208 & 59.669 & 0.774 & 0.158 & 0.035 & 0.035 \\
Median & 0.588 & 0.156 & 3.803 & 0.194 & 58.275 & 0.749 & 0.149 & 0.032 & 0.032 \\
Standrd Deviation & 0.194 & 0.010 & 1.330 & 0.099 & 15.108 & 0.239 & 0.077 & 0.043 & 0.044 \\
Skewness & -0.381 & 0.421 & 0.428 & 0.822 & 0.694 & 0.571 & 0.679 & -0.248 & -0.271 \\
Kurtosis & 2.510 & 2.570 & 2.935 & 3.650 & 3.754 & 3.787 & 4.178 & 6.240 & 6.442 \\
Obs.(CS) & 73 & 73 & 73 & 73 & 73 & 73 & 73 & 73 & 73 \\
Obs.(TS) & 31 & 31 & 31 & 31 & 31 & 31 & 31 & 31 & 31 \\
Obs.(Panel) & 2263 & 2263 & 2263 & 2263 & 2263 & 2263 & 2263 & 2263 & 2263 \\
\hline & EBITA & CFA & NIA & MARGS & OPPS & ORPS & EBITS & CFS & NIS \\
\hline Mean & 0.046 & 0.071 & 0.014 & 0.207 & 0.041 & 0.044 & 0.059 & 0.092 & 0.016 \\
Median & 0.044 & 0.067 & 0.016 & 0.201 & 0.042 & 0.040 & 0.057 & 0.088 & 0.021 \\
Standrd Deviation & 0.044 & 0.047 & 0.040 & 0.092 & 0.073 & 0.077 & 0.075 & 0.075 & 0.073 \\
Skewness & -0.291 & 0.003 & -2.606 & -0.511 & -7.015 & -6.891 & -6.748 & -5.133 & -8.942 \\
Kurtosis & 6.185 & 5.338 & 19.219 & 15.853 & 142.260 & 142.528 & 140.333 & 105.819 & 190.133 \\
Obs.(CS) & 73 & 73 & 73 & 73 & 73 & 73 & 73 & 73 & 73 \\
Obs.(TS) & 31 & 31 & 31 & 31 & 31 & 31 & 31 & 31 & 31 \\
Obs.(Panel) & 2263 & 2263 & 2263 & 2263 & 2263 & 2263 & 2263 & 2263 & 2263 \\
\hline
\end{tabular}

Notes: This table shows the descriptive statistics for the variables of the machinery industry firms listed on the Tokyo Stock Exchange First Section. The data are balanced panel data from the fiscal year of 1981 to 2011. In the table, TDA denotes the total debt (book-value) to total asset (book-value) ratio and LDA denotes the fixed liability (book-value) to total asset (book-value) ratio. In addition, LNSIZE denotes the log natural of market capitalization, TANG denotes the tangible fixed asset to total asset ratio, and OLD denotes the number of the years after establishment of each firm. Further, SALESA denotes the sales to total asset ratio, MARGA denotes the gross margin to total asset ratio, OPPA denotes the operating profit to total asset ratio, ORPA denotes the ordinary profit to total asset ratio, EBITA denotes the earnings before interest and tax (EBIT) to total asset ratio, CFA denotes the cash flow to total asset ratio, and NIA denotes the net income to total asset ratio. Further, MARGS denotes the gross margin to sales ratio, OPPS denotes the operating profit to sales ratio, ORPS denotes the ordinary profit to sales ratio, EBITS denotes the EBIT to sales ratio, CFS denotes the cash flow to sales ratio, and NIS denotes the net income to sales ratio. Further, Obs. (Panel) is the number of pooled data and Obs. (TS) (Obs. (CS)) is the number of the time-series (cross-sectional) data. 
Table 2. The relations between the corporate profitability to total asset ratio and the next year's capital structure measured by the fixed liabilities to total asset ratio: The case of the Tokyo Stock Exchange machinery industry firms

\begin{tabular}{|c|c|c|c|c|c|c|c|c|}
\hline & Model 1 & Model 2 & Model 3 & Model 4 & Model 5 & Model 6 & Model 7 & Model 8 \\
\hline Const. & $0.072 * * *$ & $0.099 * * *$ & $0.062 * * *$ & $0.065^{* * *}$ & $0.071 * * *$ & $0.069 * * *$ & $0.053 * * *$ & $0.045 * * *$ \\
\hline$p$-value & 0.000 & 0.000 & 0.000 & 0.000 & 0.000 & 0.000 & 0.000 & 0.000 \\
\hline SALESA & $-0.021 * * *$ & & & & & & & $0.015^{*}$ \\
\hline$p$-value & 0.004 & & & & & & & 0.088 \\
\hline MARGA & & $-0.279 * * *$ & & & & & & $-0.149 * * *$ \\
\hline$p$-value & & 0.000 & & & & & & 0.000 \\
\hline OPPA & & & $-0.532 * * *$ & & & & & $0.516 * * *$ \\
\hline$p$-value & & & 0.000 & & & & & 0.000 \\
\hline ORPA & & & & $-0.670 * * *$ & & & & $-2.396 * * *$ \\
\hline$p$-value & & & & 0.000 & & & & 0.000 \\
\hline EBITA & & & & & $-0.530 * * *$ & & & $1.821 * * *$ \\
\hline$p$-value & & & & & 0.000 & & & 0.000 \\
\hline CFA & & & & & & $-0.465^{* * *}$ & & -0.267 \\
\hline$p$-value & & & & & & 0.000 & & 0.103 \\
\hline NIA & & & & & & & $-0.596 * * *$ & $-0.177 * * *$ \\
\hline$p$-value & & & & & & & 0.000 & 0.007 \\
\hline LNSIZE & $0.006^{* * *}$ & $0.008 * * *$ & $0.011 * * *$ & $0.012 * * *$ & $0.011 * * *$ & $0.011 * * *$ & $0.011 * * *$ & $0.014 * * *$ \\
\hline$p$-value & 0.000 & 0.000 & 0.000 & 0.000 & 0.000 & 0.000 & 0.000 & 0.000 \\
\hline TANG & $0.350 * * *$ & $0.338 * * *$ & $0.341 * * *$ & $0.319 * * *$ & $0.329 * * *$ & $0.378 * * *$ & $0.322 * * *$ & $0.325 * * *$ \\
\hline$p$-value & 0.000 & 0.000 & 0.000 & 0.000 & 0.000 & 0.000 & 0.000 & 0.000 \\
\hline OLD & $0.0001^{* *}$ & $6.2 \mathrm{E}-05$ & $8.3 \mathrm{E}-05^{*}$ & 7.3E-05 & $7.6 \mathrm{E}-05$ & $7.2 \mathrm{E}-05$ & $0.0001 * *$ & $0.0001 * *$ \\
\hline$p$-value & 0.020 & 0.201 & 0.095 & 0.116 & 0.111 & 0.145 & 0.043 & 0.020 \\
\hline $\operatorname{Adj} . R^{2}$ & 0.189 & 0.223 & 0.229 & 0.262 & 0.233 & 0.225 & 0.237 & 0.322 \\
\hline Obs.(CS) & 73 & 73 & 73 & 73 & 73 & 73 & 73 & 73 \\
\hline Obs.(Panel) & 2190 & 2190 & 2190 & 2190 & 2190 & 2190 & 2190 & 2190 \\
\hline
\end{tabular}

Notes: This table shows the results of the panel data analyses with respect to the capital structure determinants of the Japanese machinery industry firms listed on the Tokyo Stock Exchange First Section. The analyzing period is from the fiscal year of 1981 to 2011. In this table, the dependent variable is the Japanese machinery industry firm's one year ahead capital structure variable, the fixed liability (book-value) to total asset (book-value) ratio. As to the explanatory variables, SALESA denotes the sales to total asset ratio, MARGA denotes the gross margin to total asset ratio, OPPA denotes the operating profit to total asset ratio, ORPA denotes the ordinary profit to total asset ratio, EBITA denotes the earnings before interest and tax (EBIT) to total asset ratio, CFA denotes the cash flow to total asset ratio, and NIA denotes the net income to total asset ratio. Moreover, we employ three control variables in all regressions: LNSIZE denotes the log natural of market capitalization, TANG denotes the tangible fixed asset to total asset ratio, and OLD denotes the number of the years after establishment of each firm. In addition, Const. in this table means the constant term of regressions. Further, Obs. (Panel) means the number of pooled data, Obs. (CS) means the number of cross-sectional data in each year, and $A d j . R^{2}$ is the adjusted $R$-squared value. For the statistical judgments, $* * *$ denotes the statistical significance of the coefficients at the $1 \%$ level, ${ }^{* *}$ denotes the statistical significance of the coefficients at the $5 \%$ level, and * denotes the statistical significance of the coefficients at the $10 \%$ level, respectively.

How are then our empirical results interpreted? Our results mean that first, (1) the distress cost and the tax shield effect perspectives are not empirically supported. Second, our results also indicate that (2) the agency cost theory is 
not empirically supported either. Third, our evidence indicates that (3) the pecking order theory is empirically supported, and fourth, (4) our results are consistent with the prediction from a dynamic trade-off model such as the prediction of Strebulaev (2007). Fifth, (5) our evidence is also consistent with the US empirical results by, for example, Kayhan and Titman (2007).

Table 3. The relations between the corporate profitability to sales ratio and the next year's capital structure measured by the fixed liabilities to total asset ratio: The case of the Tokyo Stock Exchange machinery industry firms

\begin{tabular}{|c|c|c|c|c|c|c|c|}
\hline & Model 1 & Model 2 & Model 3 & Model 4 & Model 5 & Model 6 & Model 7 \\
\hline Const. & $0.114 * * *$ & $0.056^{* * *}$ & $0.060 * * *$ & $0.066^{* * *}$ & $0.064 * * *$ & $0.052 * * *$ & $0.062 * * *$ \\
\hline$p$-value & 0.001 & 0.000 & 0.000 & 0.000 & 0.000 & 0.000 & 0.000 \\
\hline MARGS & $-0.346^{* * *}$ & & & & & & $-0.171 * * *$ \\
\hline$p$-value & 0.000 & & & & & & 0.000 \\
\hline OPPS & & $-0.381 * * *$ & & & & & $0.449 * * *$ \\
\hline$p$-value & & 0.000 & & & & & 0.000 \\
\hline ORPS & & & $-0.473 * * *$ & & & & $-1.939 * * *$ \\
\hline$p$-value & & & 0.000 & & & & 0.000 \\
\hline EBITS & & & & $-0.372 * * *$ & & & $1.589 * * *$ \\
\hline$p$-value & & & & 0.000 & & & 0.000 \\
\hline CFS & & & & & $-0.364 * * *$ & & $-0.306^{* * *}$ \\
\hline$p$-value & & & & & 0.000 & & 0.006 \\
\hline NIS & & & & & & $-0.344 * * *$ & -0.044 \\
\hline$p$-value & & & & & & 0.000 & 0.256 \\
\hline LNSIZE & $0.010 * * *$ & $0.011 * * *$ & $0.013 * * *$ & $0.011 * * *$ & $0.011 * * *$ & $0.010 * * *$ & $0.014 * * *$ \\
\hline$p$-value & 0.000 & 0.000 & 0.000 & 0.000 & 0.000 & 0.000 & 0.000 \\
\hline TANG & $0.340 * * *$ & $0.345 * * *$ & $0.316^{* * *}$ & $0.326^{* * *}$ & $0.377 * * *$ & $0.321 * * *$ & $0.339 * * *$ \\
\hline$p$-value & 0.000 & 0.000 & 0.000 & 0.000 & 0.000 & 0.000 & 0.000 \\
\hline OLD & 7.3E-05 & $9.1 \mathrm{E}-05^{*}$ & 7.9E- $05^{*}$ & $9.3 \mathrm{E}-05^{*}$ & $9.2 \mathrm{E}-05^{*}$ & $0.0001 * *$ & $0.0001 * *$ \\
\hline$p$-value & 0.107 & 0.073 & 0.094 & 0.056 & 0.060 & 0.032 & 0.026 \\
\hline $\operatorname{Adj} . R^{2}$ & 0.264 & 0.260 & 0.272 & 0.236 & 0.234 & 0.225 & 0.370 \\
\hline Obs.(CS) & 73 & 73 & 73 & 73 & 73 & 73 & 73 \\
\hline Obs.(Panel) & 2190 & 2190 & 2190 & 2190 & 2190 & 2190 & 2190 \\
\hline
\end{tabular}

Notes: This table shows the results of the panel data analyses as to the capital structure determinants of the Tokyo Stock Exchange First Section machinery industry firms. The analyzing period is from the fiscal year of 1981 to 2011. The dependent variable is the Japanese machinery industry firm's one year ahead fixed liability (book-value) to total asset (book-value) ratio. As to the explanatory variables, MARGS is the gross margin to sales ratio, OPPS is the operating profit to sales ratio, ORPS is the ordinary profit to sales ratio, EBITS is the EBIT to sales ratio, CFS is the cash flow to sales ratio, and NIS is the net income to sales ratio. Moreover, LNSIZE is the log natural of market capitalization, TANG is the tangible fixed asset to total asset ratio, and OLD is the number of the years after establishment of each firm. In addition, Const. in this table is the constant term of regressions. Further, Obs. (Panel) means the number of pooled data, Obs. (CS) means the number of cross-sectional data in each year, and $A d j . R^{2}$ is the adjusted $R$-squared value. For the statistical judgments, $* * *$ denotes the statistical significance of the coefficients at the $1 \%$ level, $* *$ denotes the statistical significance of the coefficients at the $5 \%$ level, and $*$ denotes the statistical significance of the coefficients at the $10 \%$ level, respectively. 
Table 4. The relations between the corporate profitability to total asset ratio and the next year's capital structure measured by the total debt to total asset ratio: The case of the Tokyo Stock Exchange machinery industry firms

\begin{tabular}{|c|c|c|c|c|c|c|c|c|}
\hline & Model 1 & Model 2 & Model 3 & Model 4 & Model 5 & Model 6 & Model 7 & Model 8 \\
\hline Const. & $0.485 * * *$ & $0.741 * * *$ & $0.333 * * *$ & $0.674 * * *$ & $0.681 * * *$ & $0.686^{* * *}$ & $0.645 * * *$ & $0.361 * * *$ \\
\hline$p$-value & 0.000 & 0.000 & 0.000 & 0.000 & 0.000 & 0.000 & 0.000 & 0.000 \\
\hline SALESA & $0.198 * * *$ & & & & & & & $0.392 * * *$ \\
\hline$p$-value & 0.000 & & & & & & & 0.000 \\
\hline MARGA & & $-0.549 * * *$ & & & & & & $-0.950 * * *$ \\
\hline$p$-value & & 0.000 & & & & & & 0.000 \\
\hline OPPA & & & $-0.894 * * *$ & & & & & $1.618 * * *$ \\
\hline$p$-value & & & 0.000 & & & & & 0.000 \\
\hline ORPA & & & & $-1.357 * * *$ & & & & $-7.984 * * *$ \\
\hline$p$-value & & & & 0.000 & & & & 0.000 \\
\hline EBITA & & & & & $-0.831 * * *$ & & & $9.768 * * *$ \\
\hline$p$-value & & & & & 0.000 & & & 0.000 \\
\hline CFA & & & & & & $-0.810 * * *$ & & $-4.084 * * *$ \\
\hline$p$-value & & & & & & 0.000 & & 0.000 \\
\hline NIA & & & & & & & $-0.991 * * *$ & $-0.189 * *$ \\
\hline$p$-value & & & & & & & 0.000 & 0.045 \\
\hline LNSIZE & $-0.013 * * *$ & $-0.009 * * *$ & $-0.005 * * *$ & -0.0005 & $-0.005 * * *$ & $-0.005^{* *}$ & $-0.004^{*}$ & $0.015 * * *$ \\
\hline$p$-value & 0.000 & 0.000 & 0.007 & 0.797 & 0.010 & 0.021 & 0.051 & 0.000 \\
\hline TANG & $-0.117 * * *$ & $-0.118 * * *$ & $-0.144 * * *$ & $-0.171 * * *$ & $-0.167 * * *$ & $-0.111 * * *$ & $-0.168 * * *$ & $0.179 * * *$ \\
\hline$p$-value & 0.000 & 0.000 & 0.000 & 0.000 & 0.000 & 0.000 & 0.000 & 0.000 \\
\hline OLD & 0.0002 & $0.0003 * *$ & $-8.1 \mathrm{E}-05$ & -0.0001 & -0.0001 & -0.0001 & $-3.3 \mathrm{E}-05$ & $0.0002 * *$ \\
\hline$p$-value & 0.157 & 0.029 & 0.499 & 0.224 & 0.330 & 0.222 & 0.781 & 0.014 \\
\hline $\operatorname{Adj} . R^{2}$ & 0.129 & 0.103 & 0.092 & 0.168 & 0.087 & 0.094 & 0.087 & 0.582 \\
\hline Obs.(CS) & 73 & 73 & 73 & 73 & 73 & 73 & 73 & 73 \\
\hline Obs.(Panel) & 2190 & 2190 & 2190 & 2190 & 2190 & 2190 & 2190 & 2190 \\
\hline
\end{tabular}

Notes: This table shows the results of the panel data analyses with respect to the capital structure determinants of the Japanese machinery industry firms listed on the Tokyo Stock Exchange First Section. The dependent variables are those in the next year and the explanatory variables are those in the current year. The analyzing period is from the fiscal year of 1981 to 2011. More concretely, in this table, the dependent variable is the Japanese machinery industry firm's one year ahead capital structure variable, total debt (book-value) to total asset (book-value) ratio. As to the explanatory variables, SALESA denotes the sales to total asset ratio, MARGA denotes the gross margin to total asset ratio, OPPA denotes the operating profit to total asset ratio, ORPA denotes the ordinary profit to total asset ratio, EBITA denotes the earnings before interest and tax (EBIT) to total asset ratio, CFA denotes the cash flow to total asset ratio, and NIA denotes the net income to total asset ratio. Moreover, we employ three control variables in all regressions: LNSIZE denotes the log natural of market capitalization, TANG denotes the tangible fixed asset to total asset ratio, and OLD denotes the number of the years after establishment of each firm. In addition, Const. in this table means the constant term of regressions. Further, Obs. (Panel) means the number of pooled data, Obs. (CS) means the number of cross-sectional data in each year, and $A d j . R^{2}$ is the adjusted $R$-squared value. For the statistical judgments, $* * *$ denotes the statistical significance of the coefficients at the $1 \%$ level, ${ }^{* *}$ denotes the statistical significance of the coefficients at the $5 \%$ level, and $*$ denotes the statistical significance of the coefficients at the $10 \%$ level, respectively. 
Table 5. The relations between the corporate profitability to sales ratio and the next year's capital structure measured by the total debt to total asset ratio: The case of the Tokyo Stock Exchange machinery industry firms

\begin{tabular}{|c|c|c|c|c|c|c|c|}
\hline & Model 1 & Model 2 & Model 3 & Model 4 & Model 5 & Model 6 & Model 7 \\
\hline Const. & $0.863 * * *$ & $0.652 * * *$ & $0.654 * * *$ & $0.672 * * *$ & $0.679 * * *$ & $0.642 * * *$ & $0.719 * * *$ \\
\hline$p$-value & 0.000 & 0.000 & 0.000 & 0.000 & 0.000 & 0.000 & 0.000 \\
\hline MARGS & $-1.105^{* * *}$ & & & & & & $-0.962 * * *$ \\
\hline$p$-value & 0.000 & & & & & & 0.000 \\
\hline OPPS & & $-0.719 * * *$ & & & & & $1.435 * * *$ \\
\hline$p$-value & & 0.000 & & & & & 0.000 \\
\hline ORPS & & & $-1.076^{* * *}$ & & & & $-5.735 * * *$ \\
\hline$p$-value & & & 0.000 & & & & 0.000 \\
\hline EBITS & & & & $-0.737 * * *$ & & & $7.231 * * *$ \\
\hline$p$-value & & & & 0.000 & & & 0.000 \\
\hline CFS & & & & & $-0.942 * * *$ & & $-2.920 * * *$ \\
\hline$p$-value & & & & & 0.000 & & 0.000 \\
\hline NIS & & & & & & $-0.575 * * *$ & $-0.138 * *$ \\
\hline$p$-value & & & & & & 0.000 & 0.022 \\
\hline LNSIZE & $-0.007 * * *$ & $-0.003^{*}$ & 0.002 & -0.003 & 0.001 & $-0.005^{* *}$ & $0.009 * * *$ \\
\hline$p$-value & 0.000 & 0.079 & 0.208 & 0.190 & 0.782 & 0.015 & 0.000 \\
\hline TANG & $-0.106^{* * *}$ & $-0.129 * * *$ & $-0.156^{* * *}$ & $-0.165 * * *$ & $-0.053 *$ & $-0.164 * * *$ & $0.220 * * *$ \\
\hline$p$-value & 0.000 & 0.000 & 0.000 & 0.000 & 0.084 & 0.000 & 0.000 \\
\hline OLD & $0.0003 * * *$ & $-6.8 \mathrm{E}-05$ & -0.0001 & -0.0001 & -0.0001 & $-2.2 \mathrm{E}-05$ & $-6.0 \mathrm{E}-05$ \\
\hline$p$-value & 0.001 & 0.569 & 0.195 & 0.311 & 0.214 & 0.853 & 0.455 \\
\hline $\operatorname{Adj} . R^{2}$ & 0.358 & 0.096 & 0.176 & 0.105 & 0.167 & 0.070 & 0.598 \\
\hline Obs.(CS) & 73 & 73 & 73 & 73 & 73 & 73 & 73 \\
\hline Obs.(Panel) & 2190 & 2190 & 2190 & 2190 & 2190 & 2190 & 2190 \\
\hline
\end{tabular}

Notes: This table shows the results of the panel data analyses with respect to the capital structure determinants of the Japanese machinery industry firms listed on the Tokyo Stock Exchange First Section. The analyzing period is from the fiscal year of 1981 to 2011. In this table, the dependent variable is the Japanese machinery industry firm's one year ahead capital structure variable, total debt (book-value) to total asset (book-value) ratio. As to the explanatory variables, MARGS denotes the gross margin to sales ratio, OPPS denotes the operating profit to sales ratio, ORPS denotes the ordinary profit to sales ratio, EBITS denotes the EBIT to sales ratio, CFS denotes the cash flow to sales ratio, and NIS denotes the net income to sales ratio. Moreover, we employ three control variables in all regressions: LNSIZE denotes the log natural of market capitalization, TANG denotes the tangible fixed asset to total asset ratio, and OLD denotes the number of the years after establishment of each firm. In addition, Const. in this table means the constant term of regressions. Further, Obs. (Panel) means the number of pooled data, Obs. (CS) means the number of cross-sectional data in each year, and $A d j \cdot R^{2}$ is the adjusted $R$-squared value. For the statistical judgments, *** denotes the statistical significance of the coefficients at the $1 \%$ level, $* *$ denotes the statistical significance of the coefficients at the $5 \%$ level, and * denotes the statistical significance of the coefficients at the $10 \%$ level, respectively.

Finally, we consider the meaning of the statistically significantly negative sign of SALESA in explaining the next year's LDA and statistically significantly positive sign of SALESA in explaining the next year's TDA. We suggest that the reason of the different sign of SALESA is because the Japanese machinery firms use more liquid debts than fixed liabilities after they experience the favorable profitability. As this result shows, we note that we should always take into consideration the operating and financing characteristic of each industry for analyzing and considering the capital structure. 


\section{Conclusions}

This paper examined the relations between firm profitability and capital structure in the Japanese machinery firms listed on the TSE First Section. We found that the linkages between firm profitability and leverage ratio were generally negative. In addition, our investigations revealed that about $60 \%$ of the total debt to total asset ratio could be explained by our firm profitability variables in the previous year. Furthermore, implications from our studies are as follows. First, (1) the distress cost and the tax shield effect perspectives are not empirically supported; second, (2) the agency cost theory is not empirically supported; third, (3) the pecking order theory is empirically supported and fourth, (4) the prediction from a dynamic trade-off model is supported. Furthermore, we consider that the Japanese machinery industry firms use more liquid liabilities than fixed liabilities after their favorable profitability based on our empirical results. Thus, we should note that it is important to pay attention to each industry's operating and financing characteristic to understand the actual capital structure in the real world.

\section{Acknowledgements}

The author thanks the Japan Society for the Promotion of Science for their generous financial assistance for this research. In addition, the author greatly thanks the kind invitation from the journal to write to this journal. Further, I also thank the Editor and anonymous referees for their kind comments to this paper.

\section{References}

Fama, E., \& French, K. R. (2002). Testing trade-off and pecking order predictions about dividends and debt. Review of Financial Studies, 15, 1-33. http://dx.doi.org/10.1111/1540-6261.00437

Fier, S. G., McCullough, K. A., \& Carson, J. M. (2013). Internal capital markets and the partial adjustment of leverage. Journal of Banking \& Finance, 37, 1029-1039. http://dx.doi.org/10.1016/j.jbankfin.2012.11.003

Frank, M. Z., \& Goyal, V. K. (2003). Testing the pecking order theory of capital structure. Journal of Financial Economics, 67, 217-248.

Frank, M. Z., \& Goyal, V. K. (2009). Capital structure decisions: Which factors are reliably important? Financial Management, 38, 1-37. http://dx.doi.org/10.1111/j.1755-053X.2009.01026.x

Gungoraydinoglu, A., \& Öztekin, Ö. (2011). Firm- and country-level determinants of corporate leverage: Some new international evidence. Journal of Corporate Finance, 17, 1457-1474. http://dx.doi.org/10.1016/j.jcorpfin.2011.08.004

Jensen, M. C., \& Meckling, W. H. (1976). Theory of the firm: Managerial behavior, agency costs and ownership structure. Journal of Financial Economics, 3, 305-360. http://dx.doi.org/10.1016/0304-405X(76)90026-X

Kayhan, A., \& Titman, S. (2007). Firms' histories and their capital structures. Journal of Financial Economics, 83, 1-32. http://dx.doi.org/10.1016/j.jfineco.2005.10.007

Lemmon, M. L., Roberts, M. R., \& Zender, J. F. (2008). Back to the beginning: Persistence and the cross-section of corporate capital structure. Journal of Finance, 63, 1575-1608. http://dx.doi.org/10.1111/j.1540-6261.2008.01369.x

Margaritis, D., \& Psillaki, M. (2010). Capital structure, equity ownership and firm performance. Journal of Banking \& Finance, 34, 621-632. http://dx.doi.org/10.1016/j.jbankfin.2009.08.023

Myers, S. C. (1984). The capital structure puzzle. Journal of Finance, 39, 575-592. http://dx.doi.org/10.1111/j.1540-6261.1984.tb03646.x

Strebulaev, I. A. (2007). Do tests of capital structure theory mean what they say? Journal of Finance, 62, 1747-1787. http://dx.doi.org/10.1111/j.1540-6261.2007.01256.x

Wu, X., \& Au Yeung, C. K. (2012). Firm growth type and capital structure persistence. Journal of Banking \& Finance, 36, 3427-3443. http://dx.doi.org/10.1016/j.jbankfin.2012.08.008 